\title{
Association analysis of polymorphisms of the CRHR1 gene with infantile spasms
}

\author{
GUANG YANG $^{1}$, LI-PING ZOU ${ }^{1,2}$, JING WANG $^{1}$, XIU-YU SHI ${ }^{1}$, XIAO-FAN YANG ${ }^{1}$, \\ BIN WANG ${ }^{1}$, YU-JIE LIU ${ }^{1}$, YAN-HONG SUN ${ }^{3}$ and FEI-YONG JIA ${ }^{4}$ \\ ${ }^{1}$ Department of Pediatrics, Chinese PLA General Hospital, Beijing 100853; ${ }^{2}$ Department of Neurology, \\ Beijing Children's Hospital, The Capital Medical University, Beijing 100045; ${ }^{3}$ Department of Pediatrics, \\ Cangzhou Central Hospital, Cangzhou, Hebei 061001; ${ }^{4}$ Department of Pediatrics, \\ First Hospital of Jilin University, Changchun, Jilin 130021, P.R. China
}

Received April 13, 2014; Accepted April 10, 2015

DOI: $10.3892 / \mathrm{mmr} .2015 .3751$

\begin{abstract}
While $>200$ types of etiologies have been shown to be involved in the pathogenesis of infantile spasms, the pathophysiology of infantile spasms remains largely elusive. Pre-natal stress and hypothalamic-pituitary-adrenal axis dysfunction were shown to be involved in the development of infantile spasms. To test the genetic association between the CRHR1 gene, which encodes the corticotrophin-releasing hormone $(\mathrm{CRH})$ receptor, and infantile spasms, five single nucleotide polymorphisms (SNPs) in the CRHR1 gene were genotyped in a sample set of 128 cases with infantile spasms and 131 healthy controls. Correlation analysis was performed on the genotyped data. Under the assumption of the dominant model, the selected five SNPs, rs4458044, rs171440, rs17689966, rs28364026 and rs242948, showed no association with the risk of infantile spasms and the effectiveness of adrenocorticotropic hormone treatment. In addition, subsequent haplotype analysis suggested none of them was associated with infantile spasms. In conclusion, the experimental results of the present study suggested no association between the CRHR1 gene and infantile spasms in a Chinese population.
\end{abstract}

\section{Introduction}

Infantile spasms, also known as the West syndrome, constitute a unique, age-specific epileptic encephalopathy of early infancy and are characterized by epileptic spasms with psychomotor regression and electroencephalographic (EEG) indication of hypsarrhythmia $(1,2)$. The incidence of infantile spasms has been estimated to be $\sim 0.31$ per 1,000 live births (3). The peak

Correspondence to: Dr Li-Ping Zou, Department of Pediatrics, Chinese PLA General Hospital, 28 Fuxing Road, Beijing 100853, P.R. China

E-mail: zouliping21@hotmail.com

Key words: infantile spasms, CRHR1 gene, single nucleotide polymorphism, haplotype age of onset of infantile spasms is three to seven months, and the condition is slightly more common in males (4). A number of underlying disorders, including perinatal brain injury, metabolic disorders and chromosome anomaly, may be the etiologies of infantile spasms (5). However, in $20 \%$ of the cases, no causes are identified (6).

While $>200$ types of etiologies have been involved in the pathogenesis of infantile spasms, the pathophysiology of infantile spasms remains largely elusive (7). Previous studies showed that pre-natal adverse stress is associated with infantile spasms in animal models and clinical epidemiological analyses $(8,9)$. Shang et al (8) found that the onset risk of infantile spasms correspondingly increased with the degree of maternal pre-natal stress. The stress may act on the developing brain and results in the dyssecretosis of the hypothalamic-pituitary-adrenal (HPA) axis and high levels of the corticotrophin-releasing hormone $(\mathrm{CRH})$, thereby causing spasms (10). Baram and Schultz (11) established a CRH rat model to verify the HPA dysfunction hypothesis. CRH administered into the cerebral ventricles of rats during the first post-natal week caused a specific and stereotyped sequence of behaviors: Rhythmic chewing and licking were followed by 'limbic'-type seizures. This condition suggested that CRH may be a strong inducer of spasms, and its excessive release may be the final common pathway through which infantile spasms were induced by various factors. On the other hand, 50-80\% of infantile spasm cases can be successfully treated with adrenocorticotropic hormone (ACTH), although infantile spasms are difficult to control with most conventional anti-epileptic drugs (12). The clinical response of infantile spasms to ACTH can be explained by the suppression of $\mathrm{CRH}$ production and release via a negative feedback mechanism (13).

The effect of $\mathrm{CRH}$ is mediated via $\mathrm{CRH}$ receptors in the cell membrane of effector organs (14). Two major CRH receptors, CRHR1 and CRHR2, have been identified and have functional differences between them (15). CRHR1 is a $\mathrm{G}$ protein-coupled receptor localized in frontal cortical areas, forebrain, brainstem, amygdala, cerebellum and the anterior pituitary (16). CRHR1 has a key role in the regulation of the HPA axis in response to stressful events, mediating the action of CRH on the pituitary gland to release ACTH that stimulates 
the production of cortisol in the adrenal cortex (17). Previous studies have shown that polymorphisms in the coding and regulatory regions of CRHR1 gene are associated with the onset of certain neuropsychiatric disorders, including major depression, bipolar disorder, alcoholism and others (18-20). However, whether genetic variants of CRHR1 are associated with infantile spasms, has not been studied in depth. In the present study, the CRHR1 gene was analyzed as a candidate to test its association with the onset of infantile spasms, as well as its responsiveness to ACTH treatment.

\section{Materials and methods}

Study subjects. A total of 128 patients with infantile spasms and 131 healthy controls were recruited to perform the case-control analysis. The cases were unrelated Chinese individuals ( 83 boys, 45 girls; mean age, $6.8 \pm 2.9$ months), recruited between January 2006 and May 2010 from the Chinese PLA General Hospital and Beijing Children's Hospital affiliated to Capital Medical University (Beijing, China). The diagnostic criteria for infantile spasms were as follows: 1) The presence of epileptic spasms; 2) hypsarrhythmia or modified hypsarrhythmia indicated by EEG prior to treatment; and 3) onset of the infantile spasms at an age between one month and two years (12). According to etiologies, infantile spasms were classified as symptomatic or cryptogenic, as defined by the International League Against Epilepsy (21). Clinical evaluation was performed by experienced pediatric neurologists. Individuals were excluded from the study if they had received hormone therapy within 28 days prior to recruitment or if they displayed contraindications to hormone therapy. The control subjects were all unrelated Chinese individuals ( 87 boys, 44 girls; mean age, $7.5 \pm 3.7$ months) without any nervous system diseases, particularly epilepsy, or family history of epilepsy. No statistical difference existed between the patients and controls in terms of gender and age (Table I). All subjects of the present study were Han Chinese, and their parents were asked to sign written informed consent prior to enrolement in this study. The study was approved by the Committee on Human Study of Beijing Children's Hospital affiliated to Capital Medical University (Beijing, China).

Evaluation of effectiveness of ACTH treatment. Patients with infantile spasms received ACTH (Shanghai First Biochemical Pharmaceutical Co., Shanghai, China) treatment 25 U/day intravenously for 3 weeks. ACTH response was evaluated mainly based on changes in seizure frequency. Baseline seizure frequency was assessed by parents or carers. Three weeks after ACTH treatment initiation, the seizure frequency was assessed again. Changes in seizure frequency were classified as seizure-free (cessation of seizure for $\geq 7$ days), reduced (reduction of the baseline frequency by $50-<100 \%$ ), unchanged (reduction of the baseline frequency by $<50 \%$ ), or increased $(>100 \%)$. The rate of response, defined as a cessation and reduction of the baseline seizure frequency by $\geq 50 \%$, was calculated in each group. No change or increased frequency was defined as no response.

Selection of single nucleotide polymorphisms (SNPs). The human CRHR1 gene (NM_004382) contains 13 exons and
Table I. Distribution of selected variables in cases $(n=128)$ and controls $(n=131)$.

\begin{tabular}{lccc}
\hline Variable & Cases & Controls & P-value \\
\hline Gender & & & $0.79^{\mathrm{a}}$ \\
$\quad$ Male, $\mathrm{n}(\%)$ & $83(64.8)$ & $87(66.4)$ & \\
Female, $\mathrm{n}(\%)$ & $45(35.2)$ & $44(33.6)$ & \\
Age (months) & $6.8 \pm 2.9$ & $7.5 \pm 3.7$ & $0.88^{\mathrm{b}}$ \\
ACTH responsiveness & & & \\
$\quad$ Response (n) & 62 & 63.9 & \\
$\quad$ No response (n) & 35 & 36.1 & \\
Etiology & & & \\
$\quad$ Symptomatic (n) & 79 & 70.5 & \\
Cryptogenic (n) & 33 & 29.5 & \\
\hline
\end{tabular}

Age is expressed as the mean \pm standard deviation. ${ }^{\text {aTwo-sided }} \chi^{2}$ test; bindependent-samples T test. ACTH, adrenocorticotropic hormone.

spans $51.5 \mathrm{~kb}$ of the sequence on chromosome 17. Based on the HapMap Genome Browser (Phase 1 and 2 - full dataset; http://hapmap.ncbi.nlm.nih.gov/), the tagSNP and functional SNP strategy with a minor allele frequency $(\mathrm{MAF})>0.1$ were used on a Chinese population, and five SNPs were selected for genotyping in the present study. One SNP, rs28364026, in the 3' untranslated region (3'UTR), one SNP, rs242948, in the 3 ' neargene region, and all other three SNPs were in introns.

Genotyping assay. Genomic DNA was extracted from peripheral blood lymphocytes using the Qiagen QIAamp DNA Blood mini kit (Qiagen Inc., Hilden, Germany) according to the manufacturer's instructions. Genotyping primers were designed using the Primer3 software (http://frodo.wi.mit. edu/cgi-bin/primer3/primer3_results.cgi), and the sequences are listed in Table II. Multiplex polymerase chain reactions (PCR) were used to amplify all fragments in a total reaction volume of $20 \mu 1$. The amplification reactions contained 1X HotStarTaq buffer, $3.0 \mathrm{mM} \mathrm{Mg}{ }^{2+}, 0.3 \mathrm{mM}$ desoxynucleoside triphosphate, 1U HotStarTaq polymerase (Qiagen Inc.), 10 ng sample DNA and $1 \mu 1$ multiple PCR primer. All primers were supplied by Beijing SaiBaiSheng Gene Technology Co., Ltd. (Beijing, China). The PCR amplification was performed using a PTC-200 thermocycler (MJ Research, Watertown, MA, USA). The cycling conditions for PCR in all reactions included an initial activation step at $95^{\circ} \mathrm{C}$ for 15 minutes, followed by 11 cycles of denaturation at $94^{\circ} \mathrm{C}$ for 20 seconds, touchdown annealing at $65^{\circ} \mathrm{C}$ for 40 seconds $-0.5^{\circ} \mathrm{C}$ per cycle, extension at $72^{\circ} \mathrm{C}$ for 90 seconds, followed by another 24 cycles of denaturation at $94^{\circ} \mathrm{C}$ for 20 seconds, annealing at $59^{\circ} \mathrm{C}$ for 30 seconds, extension at $72^{\circ} \mathrm{C}$ for 90 seconds, and finally, extension at $72^{\circ} \mathrm{C}$ for 4 minutes. After the completion of PCR amplification, phosphatase alkaline shrimp (SAP) and exonuclease I (Exo I) were used to purify the PCR products. One unit of SAP and 1 unit of Exo I were added to $5 \mu 1$ PCR mixture. The mixture was incubated at $37^{\circ} \mathrm{C}$ for 1 hour, followed by inactivation at $75^{\circ} \mathrm{C}$ for 15 minutes. Snap-shot multiplex single-base extension 
Table II. Primer information of NR3C1 for snapshot assay.

\begin{tabular}{|c|c|c|c|c|}
\hline rs number & Direction & Primer sequence & $\operatorname{Tm}\left({ }^{\circ} \mathrm{C}\right)$ & Product size (bp) \\
\hline \multirow[t]{2}{*}{ rs171440 } & Forward & GGATGGGTCTGTTCCAGGGTGT & 66.09 & 214 \\
\hline & Reverse & TGGTCCCCTGCTCTGTAGCCTAA & 65.96 & \\
\hline \multirow[t]{2}{*}{ rs4458044 } & Forward & TGGGCTCCССТCTTCTGTGAG & 65.66 & 106 \\
\hline & Reverse & CTGCСТTCССТTCССТССТСТT & 64.42 & \\
\hline \multirow[t]{2}{*}{ rs17689966 } & Forward & CCTTCTGCCAGGGTTGGAATTG & 64.63 & 212 \\
\hline & Reverse & ATCATGGGGCCCTGGTAGATGT & 64.92 & \\
\hline \multirow[t]{2}{*}{ rs28364026 } & Forward & CTGCCTGTGGAGGTGACCTGTT & 63.68 & 158 \\
\hline & Reverse & CCCCATTTCAATTCATTCCCATGT & 64.11 & \\
\hline \multirow[t]{2}{*}{ rs242948 } & Forward & ATGGGTCAGGGGAAGGAACAAA & 64.59 & 176 \\
\hline & Reverse & TGGAGACAGCTGCATTCACAGC & 64.70 & \\
\hline
\end{tabular}

I

I

I I I

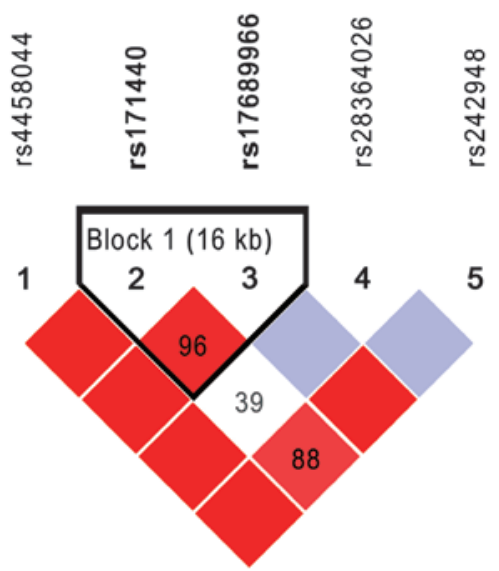

Figure 1. Reconstructed linkage disequilibrium map using five single nucleotide polymorphisms of CRHR1. The haplotype block was determined using haploview software. rs numbers are stated on top, and the numbers in the squares represent the $\mathrm{D}^{\prime}$ values.

was performed using the SnaPshot Multiplex kit (Applied Biosystems, Life Technologies, Thermo Fisher Scientific, Waltham, MA, USA) with five different extension primers. The 10- $\mu$ l extension mix contained $5 \mu$ l SnaPshot Multiplex reagent, $2 \mu \mathrm{l}$ purified multiplex PCR products, $1 \mu \mathrm{l}$ extension primer mix and $2 \mu \mathrm{l}$ double distilled $\mathrm{H}_{2} \mathrm{O}$. The extension PCR cycling conditions included an initial activation step at $96^{\circ} \mathrm{C}$ for 1 minute, followed by 28 cycles of denaturation at $96^{\circ} \mathrm{C}$ for 10 seconds, annealing at $50^{\circ} \mathrm{C}$ for 5 seconds and extension at $60^{\circ} \mathrm{C}$ for 30 seconds. The $10-\mu$ l extension PCR product obtained by extension PCR was purified with $1 \mathrm{U}$ SAP at $37^{\circ} \mathrm{C}$ for 1 hour, followed by an inactivation at $75^{\circ} \mathrm{C}$ for 15 minutes. Pyrosequencing was performed on the ABI3130XL sequencer (Applied Biosystems). Data were collected and analyzed using GeneMapper 4.0 (Applied Biosystems).

Statistical analysis. Differences in gender as well as frequencies of alleles and genotypes between cases and controls were tested using Pearson's $\chi^{2}$ test. An independent-samples T test was used to examine the difference in age between controls and cases. Pearson's $\chi^{2}$ test was also employed to examine the different allelic frequencies of ACTH effectiveness and etiology in cases. The Hardy-Weinberg equilibrium test was performed for every SNP in the controls. The linkage disequilibrium (LD) blocks were reconstructed with D' and r2 using Haploview software (http://www.broadinstitute.org/haploview) and pairwise linkage disequilibrium values $D^{\prime}$ and $\mathrm{r} 2$ were calculated in the control population using the maximum likelihood method. Haplotype blocks were defined using the method of Gabriel et al (22). Each samples' haplotype and dihaplotype was estimated from the genotype data using PHASE 2.0.2 software (available on request). Odds ratios (OR) and $95 \%$ confidence intervals (95\% CI) were calculated using unconditional logistic regression analysis to evaluate the association between the risk of infantile spasms and each SNP or haplotype or dihaplotype, and adjusted to age and gender. All statistical tests were performed using SPSS 20.0 software (International Business Machines, Armonk, NY, USA). Two-sided P-values $<0.05$ were considered to indicate statistically significant differences between values.

\section{Results}

In the present study, 128 cases with infantile spasms and 131 controls were examined who were all unrelated Han Chinese children. There was no significant difference between cases and control group regarding gender and age $(\mathrm{P}>0.05)$. Table I shows basic data on the subjects.

The positions and MAFs of five SNPs of the CRHR1 gene in the National Center for Biotechnology Information database for Han Chinese in Beijing are shown in Table III. Each SNP was examined with Hardy-Weinberg equilibrium among controls, and no significant difference was observed $(\mathrm{P}>0.05)$. Hence, the population was qualified for further analyses. The genotyping rates of five SNPs were all $>99.6 \%$.

The association of five SNPsin theCRHR1 gene was examined in a dominant model adjusted to age and gender, but no significant differences were identified by Pearson's $\chi^{2}$ test between cases and controls regarding each SNP (Table IV). The LD block of the five SNPs was reconstructed using the genotyping data of the 
controls with the haploview software. Fig. 1 shows the LD blocks among five SNPs, where two SNPs, rs171440 and rs17689966, were able to form an LD block. PHASE software was used to estimate the possible haplotypes and diplotypes between rs171440 and rs17689966. There were three haplotypes and three common diplotypes, but none of them was found to be associated with the risk of infantile spasms (Table V).

A total of 97 patients with infantile spasms received ACTH treatment for three weeks, among which 62 cases (63.9\%) showed responses and 35 cases (36.1\%) were unresponsive. The association of ACTH responsiveness and the genotypes of SNPs was analyzed. Under the assumption of a co-dominant model, there was no association of the effectiveness of ACTH and the etiology of infantile spasms with any single SNP (Table VI).

\section{Discussion}

Infantile spasms are a devastating epileptic syndrome in children and have unique features, including characteristic epileptic spasms during infancy, specific electrographic hypsarrhythmia and the arrest of psychomotor development (23). However, the exact pathophysiology of infantile spasms has remained elusive. In the CRH-excess hypothesis, an excessively abnormal secretion of CRH induced by different stressors in the developing brain is thought to increase excitatory amino acid neurotransmission, thereby causing spasms (24). ACTH being the only effective drug for infantile spasms apart from vigabatrin indicates that infantile spasms may be fundamentally different from other epileptic syndromes (1). The clinical response to ACTH can be explained by the suppression of $\mathrm{CRH}$ production through negative feedback (10). Based on the effectiveness of ACTH treatment and the HPA axis dysfunction hypothesis, Shi et al (25) have proposed a pre-natal stress exposure hypothesis, stating that diverse etiological factors are the onset foundations of infantile spasms, whereas adverse stress during the perinatal period is the onset condition of infantile spasms.

In spite of the large amount of available studies on infantile spasms, genetic studies on the association between polymorphisms of genes and infantile spasms are limited. SNPs are the most common genetic variations with a frequency $>1 \%$ in humans. Liu et al (26) found that the haplotype TCCT in the MC2R promoter is strongly associated with the responsiveness of ACTH therapy in patients with infantile spasms. Further, experiments were conducted to evaluate the function of TCCT in vitro, demonstrating that TCCT leads to an increased expression of MC2R and a strong response to ACTH (27). Ding et al (28) also reported that the response to $\mathrm{ACTH}$ treatment in the CTA haplotype of GRIN1 in homozygous-carriers was higher than that in heterozygous-carriers and non-carriers.

The CRHR1 gene, located at 17q12-q22, encodes a $\mathrm{G}$ protein-coupled receptor that binds neuropeptides of the CRH family, which are major regulators of the HPA pathway (29). The encoded protein is essential for the activation of signal transduction pathways that regulate diverse physiological processes, including stress, reproduction, immune response and obesity (30). Polymorphisms in the 
Table IV. Genotypes of five single nucleotide polymorphisms of CRHR1 and their associations with infantile spasms.

\begin{tabular}{|c|c|c|c|c|c|c|}
\hline \multirow[b]{2}{*}{ Genetic model } & \multirow[b]{2}{*}{ Genotype } & \multirow[b]{2}{*}{ Controls, n (\%) } & \multirow[b]{2}{*}{ Cases, n (\%) } & \multirow[b]{2}{*}{ P-value } & \multicolumn{2}{|c|}{ Logistic regression $^{\mathrm{b}}$} \\
\hline & & & & & OR $(95 \% \mathrm{CI})^{\mathrm{c}}$ & P-value ${ }^{d}$ \\
\hline \multicolumn{7}{|l|}{ rs4458044 } \\
\hline \multirow[t]{3}{*}{ Co-dominant } & GG & $67(51.1)$ & $57(44.5)$ & & 1.00 & \\
\hline & $\mathrm{GC}$ & $51(38.9)$ & $64(50)$ & 0.13 & $1.47(0.88-2.45)$ & 0.14 \\
\hline & $\mathrm{CC}$ & $13(10)$ & $7(5.5)$ & & $0.63(0.23-1.68)$ & 0.35 \\
\hline Dominant & $\mathrm{GC}+\mathrm{CC}$ & $64(48.9)$ & $71(55.5)$ & 0.29 & $1.30(0.80-2.12)$ & 0.29 \\
\hline \multicolumn{7}{|l|}{ rs 171440} \\
\hline \multirow[t]{3}{*}{ Co-dominant } & AA & $100(76.3)$ & $96(75)$ & & 1.00 & \\
\hline & $\mathrm{AG}$ & $29(22.1)$ & $32(25)$ & 0.33 & $1.15(0.65-2.05)$ & 0.64 \\
\hline & GG & $2(1.6)$ & 0 & & & 0.99 \\
\hline Dominant & $\mathrm{AG}+\mathrm{GG}$ & $31(23.7)$ & $32(25)$ & 0.80 & $1.08(0.61-1.91)$ & 0.80 \\
\hline \multicolumn{7}{|l|}{ rs17689966 } \\
\hline \multirow[t]{3}{*}{ Co-dominant } & $\mathrm{AA}$ & 87 (66.9) & $88(68.8)$ & & 1.00 & \\
\hline & $\mathrm{AG}$ & $39(30)$ & $36(28.1)$ & 0.78 & $0.92(0.53-1.60)$ & 0.77 \\
\hline & GG & $4(3.1)$ & $4(3.1)$ & & $0.98(0.24-4.06)$ & 0.97 \\
\hline Dominant & $\mathrm{AG}+\mathrm{GG}$ & $43(33.1)$ & $40(31.2)$ & 0.75 & $0.93(0.55-1.57)$ & 0.78 \\
\hline \multicolumn{7}{|l|}{ rs28364026 } \\
\hline \multirow[t]{3}{*}{ Co-dominant } & GG & $83(63.4)$ & 79 (61.7) & & 1.00 & \\
\hline & GA & $43(32.8)$ & $45(35.2)$ & 0.90 & $1.10(0.66-1.86)$ & 0.71 \\
\hline & $\mathrm{AA}$ & $5(3.8)$ & $4(3.1)$ & & $0.85(0.22-3.29)$ & 0.81 \\
\hline Dominant & $\mathrm{GA}+\mathrm{AA}$ & $48(36.6)$ & $49(38.3)$ & 0.79 & $1.08(0.65-1.78)$ & 0.77 \\
\hline \multicolumn{7}{|l|}{ rs242948 } \\
\hline \multirow[t]{3}{*}{ Co-dominant } & $\mathrm{TT}$ & $92(70.2)$ & $88(68.8)$ & & 1.00 & \\
\hline & TG & $35(26.7)$ & $36(28.1)$ & 0.97 & $1.09(0.63-1.90)$ & 0.76 \\
\hline & GG & $4(3.1)$ & $4(3.1)$ & & $1.03(0.25-4.26)$ & 0.97 \\
\hline Dominant & $\mathrm{TG}+\mathrm{GG}$ & $39(29.8)$ & $40(31.2)$ & 0.80 & $1.08(0.63-1.85)$ & 0.77 \\
\hline
\end{tabular}

aP-value for genotype frequencies in cases and controls using the two-sided $\chi^{2}$ test; ${ }^{b}$ Adjusted by age and gender.

Table V. Association of haplotypes and diplotypes with risk of infantile spasms.

\begin{tabular}{|c|c|c|c|c|}
\hline \multirow[b]{2}{*}{ Types } & \multirow[b]{2}{*}{ Controls, n (\%) } & \multirow[b]{2}{*}{ Cases, n (\%) } & \multicolumn{2}{|c|}{ Logistic regression $^{\mathrm{a}}$} \\
\hline & & & OR $(95 \% \mathrm{CI})$ & P-value ${ }^{b}$ \\
\hline \multicolumn{5}{|c|}{ Haplotypes ${ }^{\mathrm{c}}$} \\
\hline $\mathrm{AA}$ & $214(82)$ & $212(82.8)$ & 1.00 & \\
\hline $\mathrm{AG}$ & $15(5.7)$ & $12(4.7)$ & $0.82(0.37-1.80)$ & 0.62 \\
\hline GG & $32(12.3)$ & $32(12.5)$ & $1.01(0.60-1.71)$ & 0.98 \\
\hline \multicolumn{5}{|c|}{ Diplotypes $^{\mathrm{c}}$} \\
\hline $\mathrm{AA} / \mathrm{AA}$ & $88(67.2)$ & $88(68.8)$ & 1.00 & \\
\hline $\mathrm{AA} / \mathrm{AG}$ & $12(9.2)$ & $8(6.3)$ & $0.68(0.26-1.78)$ & 0.43 \\
\hline $\mathrm{AA} / \mathrm{GG}$ & $26(19.8)$ & $28(21.9)$ & $1.08(0.59-2.00)$ & 0.80 \\
\hline Others $^{\mathrm{d}}$ & $5(3.8)$ & $4(3)$ & $0.80(0.21-3.08)$ & 0.74 \\
\hline
\end{tabular}

${ }^{\mathrm{a}}$ Adjusted by age and gender; ${ }^{\mathrm{b}} \mathrm{P}-\mathrm{value}$ from unconditional logistic regression analysis; ${ }^{\mathrm{C}}$ haplotypes and diplotypes were composed of two single nucleotide polymorphisms, rs171440 and rs17689966; dothers: Diplotypes, AG/GG and GG/GG, with frequencies <0.03. OR, odds ratio; CI confidence interval. 


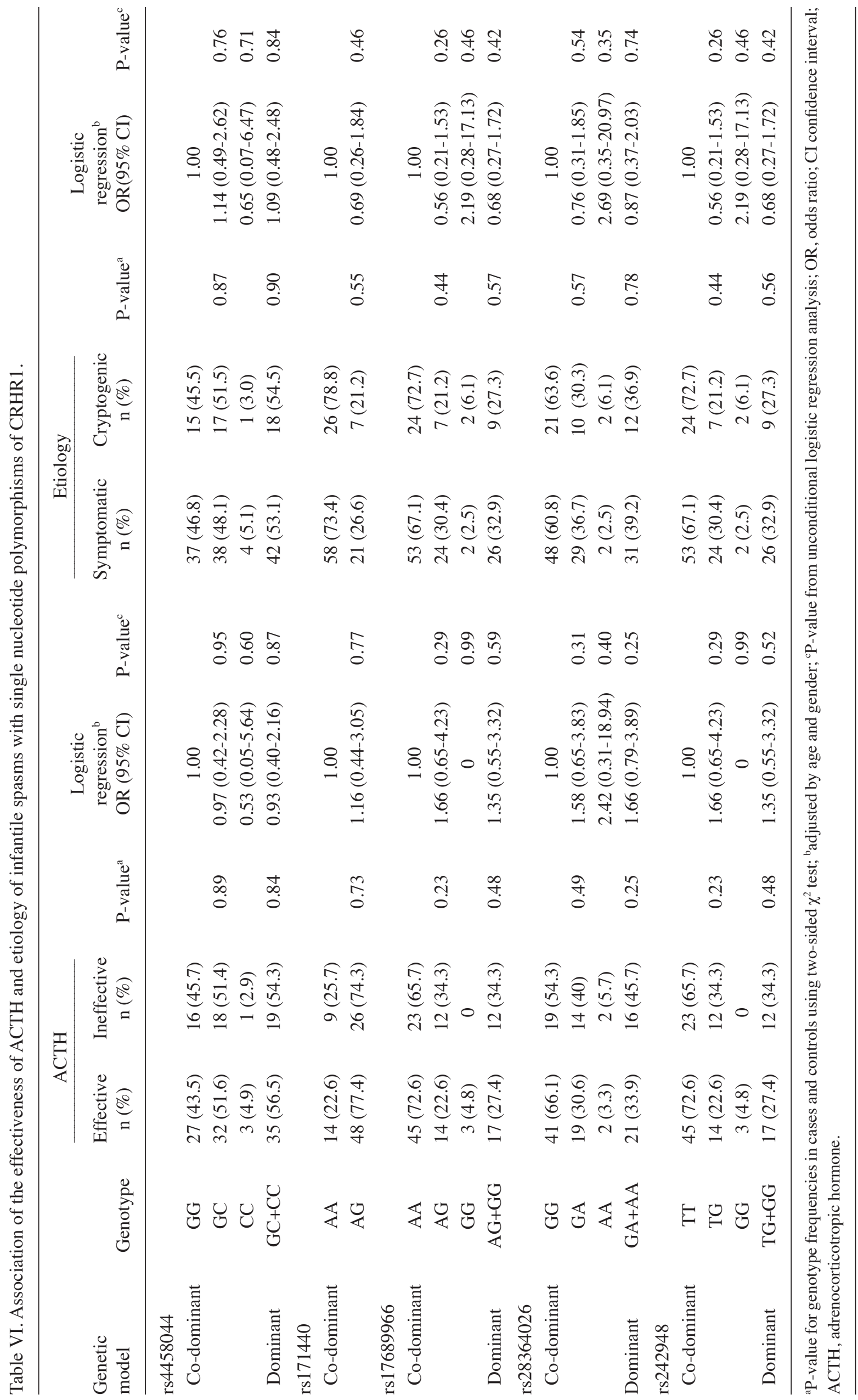


CRHR1 gene have been implicated in the susceptibility for certain neuropsychiatric disorders, particularly under conditions of stress, including major depression, alcoholism and child abuse (31-33). Geng et al (31) found that a functional polymorphism in the 3'UTR of the CRHR1 gene (rs28364032) and three haplotypes containing it showed significant associations with anti-depressant remission. Haplotype analyses of the CRHR1 gene in 2,533 unrelated Caucasian individuals identified one haplotype in the proximal block 1 and two haplotypes in the distal block 2 that showed nominally significant genotype - traumatic stress interactive effects on the likelihood of developing alcoholism (corrected $\mathrm{P}<0.025$ ) (32). Grabe et al (33) reported an association between childhood abuse and the TAT-haplotype of the CRHR1 gene and adult depression, therefore connecting childhood adversities and genetic susceptibility to neurological disorders. The present study hypothesized that CRHR1 is involved in the development of infantile spasms, and to the best of our knowledge, no studies have been conducted regarding the association between the polymorphisms of CRHR1 and infantile spasms to date.

In the present study, CRHR1 was selected as a candidate gene to investigate its association with the risk of infantile spasms and the effectiveness of ACTH treatment. Although cryptogenic cases may rather be associated with hereditary susceptibility, symptomatic and cryptogenic cases were all enrolled in the present study, as not all symptomatic pathogens, including perinatal asphyxia, congenital malformations and tuberous sclerosis, will result in infantile spasms. Thus, genetic factors may also contribute to symptomatic disorders, which has indeed been confirmed by previous studies (34). Under the assumption of the dominant model, the selected five SNPs, rs4458044, rs171440, rs17689966, rs28364026 and rs242948, showed no association with the risk of infantile spasms and the efficacy of ACTH treatment. In addition, subsequent haplotype analysis suggested that none of them was associated with the risk of infantile spasms.

In spite of the strong rationale of the present study, the case-control results did not reveal any statistically significant associations between polymorphisms in the CRHR 1 gene and infantile spasms. It is, however, possible that rare variants in the CRHR1 gene may have a role in the onset of infantile spasms and the effect of such polymorphisms may not have been detected in the relatively small population of infantile spasm cases enrolled in the present study. In order to detect the effect of rare variations in the CRHR1 gene using a case control methodology, a significantly larger number of infantile spasms and control individuals would be required to be analyzed. Alternatively, it may be possible to identify rare but important variations in the CRHR1 gene by directly sequencing regions of the CRHR 1 gene in a smaller sample of infantile spasms and control individuals.

In conclusion, the present study presented a preliminary evaluation of the role of variations in the CRHR 1 gene in infantile spasms. It was the first attempt to study the impact of polymorphisms in the CRHR1 gene in Chinese individuals with infantile spasms. While the present study failed to detect any significant associations between individual SNPs or haplotypes in the CRHR1 gene with the infantile spasm phenotype, it is still possible that variations in this gene may impact the development or progression of this illness.

\section{Acknowledgements}

This study was supported by grants from the National Natural Science Foundation of China (nos. 30770747, 30801249, 81071036 and 81211140048), the Beijing Municipal Natural Science Foundation (nos. 7142150, 7081002 and 7042024) and the Capital Characteristic Clinical Application Research Foundation (no. Z121107001012056).

\section{References}

1. Hrachovy RA and Frost JD Jr: Infantile spasms. Handb Clin Neurol 111: 611-618, 2013.

2. Pavone P, Striano P, Falsaperla R, Pavone L and Ruggieri M: Infantile spasms syndrome, West syndrome and related phenotypes: What we know in 2013. Brain Dev 36, 739-751, 2014.

3. Trevathan E, Murphy CC and Yeargin-Allsopp M: The descriptive epidemiology of infantile spasms among Atlanta children. Epilepsia 40: 748-751, 1999.

4. Go CY, Mackay MT, Weiss SK, Stephens D, Adams-Webber T, Ashwal S and Snead OC III; Child Neurology Society; American Academy of Neurology: Evidence-based guideline update: Medical treatment of infantile spasms. Report of the Guideline Development Subcommittee of the American Academy of Neurology and the Practice Committee of the Child Neurology Society. Neurology 78: 1974-1980, 2012.

5. Osborne JP, Lux AL, Edwards SW, Hancock E, Johnson AL, Kennedy CR, Newton RW, Verity CM and O'Callaghan FJ: The underlying etiology of infantile spasms (West syndrome): Information from the United Kingdom Infantile Spasms Study (UKISS) on contemporary causes and their classification. Epilepsia 51: 2168-2174, 2010.

6. Sogawa Y and Moshe SL: Catastrophic epilepsies: Clinical controversies of infantile spasms. Neurol Asia 15: 5-7, 2010.

7. Paciorkowski AR, Thio LL and Dobyns WB: Genetic and biologic classification of infantile spasms. Pediatr Neurol 45: 355-367, 2011.

8. Shang NX, Zou LP, Zhao JB, Zhang F and Li H: Association between prenatal stress and infantile spasms: A case-control study in China. Pediatr Neurol 42: 181-186, 2010.

9. Wang YJ, Zhang Y, Liang XH, Yang G and Zou LP: Effects of adrenal dysfunction and high-dose adrenocorticotropic hormone on NMDA-induced spasm seizures in young Wistar rats. Epilepsy Res 100: 125-131, 2012.

10. Stafstrom CE: Infantile spasms: A critical review of emerging animal models. Epilepsy Curr 9: 75-81, 2009.

11. Baram TZ and Schultz L: Corticotropin-releasing hormone is a rapid and potent convulsant in the infant rat. Brain Res Dev Brain Res 61: 97-101, 1991.

12. Pellock JM, Hrachovy R, Shinnar S, Baram TZ, Bettis D, Dlugos DJ, Gaillard WD, Gibson PA, Holmes GL, Nordl DR, et al: Infantile spasms: A U.S. consensus report. Epilepsia 51: 2175-2189, 2010.

13. Brunson KL, Avishai-Eliner S and Baram TZ: ACTH treatment of infantile spasms: Mechanisms of its effects in modulation of neuronal excitability. Int Rev Neurobiol 49: 185-197, 2002.

14. Wypior G, Jeschke U, Kurpisz M and Szekeres-Bartho J: Expression of $\mathrm{CRH}, \mathrm{CRH}$-related peptide and $\mathrm{CRH}$ receptor in the ovary and potential CRH signalling pathways. J Reprod Immunol 90: 67-73, 2011.

15. Zoumakis E, Kalantaridou $\mathrm{SN}$ and Makrigiannakis A: $\mathrm{CRH}$-like peptides in human reproduction. Curr Med Chem 16: 4230-4235, 2009.

16. Hauger RL, Risbrough V, Brauns O and Dautzenberg FM: Corticotropin releasing factor (CRF) receptor signaling in the central nervous system: New molecular targets. CNS Neurol Disord Drug Targets 5: 453-479, 2006.

17. Bogdan R, Santesso DL, Fagerness J, Perlis RH and Pizzagalli DA: Corticotropin-releasing hormone receptor type 1 (CRHR1) genetic variation and stress interact to influence reward learning. J Neurosci 31: 13246-13254, 2011.

18. Liu Z, Liu W, Yao L, Yang C, Xiao L, Wan Q, Gao K, Wang H, Zhu F, Wang G, et al: Negative life events and corticotropin-releasing-hormone receptorl gene in recurrent major depressive disorder. Sci Rep 3: 1548, 2013. 
19. Heim C, Bradley B, Mletzko TC, Deveau TC, Musselman DL, Nemeroff CB, Ressler KJ and Binder EB: Effect of childhood trauma on adult depression and neuroendocrine function: Sex-specific moderation by CRH receptor 1 gene. Front Behav Neurosci 3: 41, 2009.

20. Chen AC, Manz N, Tang Y, Rangaswamy M, Almasy L, Kuperman S, Nurnberger J Jr, O'Connor SJ, Edenberg HJ, Schuckit MA, et al: Single-nucleotide polymorphisms in corticotropin releasing hormone receptor 1 gene (CRHR1) are associated with quantitative trait of event-related potential and alcohol dependence. Alcohol Clin Exp Res 34: 988-996, 2010.

21. Engel J Jr; International League Against Epilepsy (ILAE): A proposed diagnostic scheme for people with epileptic seizures and with epilepsy: Report of the ILAE Task Force on Classification and Terminology. Epilepsia 42: 796-803, 2001.

22. Gabriel SB, Schaffner SF, Nguyen H, Moore JM, Roy J, Blumenstiel B, Higgins J, DeFelice M, Lochner A, Faggart M, et al: The structure of haplotype blocks in the human genome. Science 296: 2225-2229, 2002

23. Lux AL: Latest American and European updates on infantile spasms. Curr Neurol Neurosci Rep 13: 334, 2013.

24. Brunson KL, Eghbal-Ahmadi M and Baram TZ: How do the many etiologies of West syndrome lead to excitability and seizures? The corticotropin releasing hormone excess hypothesis. Brain Dev 23: 533-538, 2001

25. Shi XY, Zou LP, Yang G and Ding YX: Prenatal stress exposure hypothesis for infantile spasms. Med Hypotheses 78: 735-737, 2012.

26. Liu ZL, He B, Fang F, Tang CY and Zou LP: Genetic polymorphisms of MC2R gene associated with responsiveness to adrenocorticotropic hormone therapy in infantile spasms. Chin Med J (Engl) 121: 1627-1632, 2008.
27. Ding YX, Zou LP, He B, Yue WH, Liu ZL and Zhang D: ACTH receptor $(\mathrm{MC} 2 \mathrm{R})$ promoter variants associated with infantile spasms modulate MC2R expression and responsiveness to ACTH. Pharmacogenet Genomics 20: 71-76, 2010.

28. Ding YX, Zhang Y, He B, Yue WH, Zhang D and Zou LP: A possible association of responsiveness to adrenocorticotropic hormone with specific GRIN1 haplotypes in infantile spasms. Dev Med Child Neurol 52: 1028-1032, 2010.

29. Wasserman D, Wasserman J and Sokolowski M: Genetics of HPA-axis, depression and suicidality. Eur Psychiatry 25: 278-280, 2010.

30. Aguilera G, Nikodemova M, Wynn PC and Catt KJ: Corticotropin releasing hormone receptors: Two decades later. Peptides 25: 319-329, 2004

31. Geng LY, Ye DQ, Shi YY, Xu Z, Pu MJ, Li ZY, Li XL, Li Y and Zhang ZJ: Influence of genetic polymorphisms involved in the hypothalamic-pituitary-adrenal axis and their interactions with environmental factors on antidepressant response. CNS Neurosci Ther 20: 237-243, 2014.

32. Ray LA, Sehl M, Bujarski S, Hutchison K, Blaine S and Enoch MA: The CRHR1 gene, trauma exposure, and alcoholism risk: A test of $\mathrm{G} \times \mathrm{E}$ effects. Genes Brain Behav 12: 361-369, 2013.

33. Grabe HJ, Schwahn C, Appel K, Mahler J, Schulz A, Spitzer C, Fenske K, Barnow S, Lucht M, Freyberger HJ, et al: Childhood maltreatment, the corticotropin-releasing hormone receptor gene and adult depression in the general population. Am J Med Genet B Neuropsychiatr Genet 153B: 1483-1493, 2010.

34. Yang G, Zou LP, He B, Ding YX, Wang J, Shi XY, Sun YH and Jia FY: NR3C1 gene polymorphism for genetic susceptibility to infantile spasms in a Chinese population. Life Sci 91: 37-43, 2012. 